\title{
Pathogenesis of Type 2 Epithelial to Mesenchymal Transition (EMT) in Renal and Hepatic Fibrosis
}

\author{
Anusha H. Tennakoon ${ }^{1,2}$, Takeshi Izawa ${ }^{1}$, Mitsuru Kuwamura ${ }^{1}$ and Jyoji Yamate ${ }^{1, *}$ \\ Received: 30 November 2015; Accepted: 24 December 2015; Published: 30 December 2015 \\ Academic Editors: David A. Brenner, Tatiana Kisseleva and Jonas Fuxe \\ 1 Laboratory of Veterinary Pathology, Life and Environmental Sciences, Osaka Prefecture University, \\ Rinkuu Ourai Kita 1-58, Izumisano, Osaka 598-8531, Japan; tennakoonah@gmail.com (A.H.T.); \\ izawa@vet.osakafu-u.ac.jp (T.I.); kuwamura@vet.osakafu-u.ac.jp (M.K.) \\ 2 Teaching Hospital Peradeniya, Peradeniya 20400, Sri Lanka \\ * Correspondence: yamate@vet.osakafu-u.ac.jp; Tel.: +81-72-463-5334; Fax: +81-72-463-5346
}

\begin{abstract}
Epithelial to mesenchymal transition (EMT), particularly, type 2 EMT, is important in progressive renal and hepatic fibrosis. In this process, incompletely regenerated renal epithelia lose their epithelial characteristics and gain migratory mesenchymal qualities as myofibroblasts. In hepatic fibrosis (importantly, cirrhosis), the process also occurs in injured hepatocytes and hepatic progenitor cells (HPCs), as well as ductular reaction-related bile epithelia. Interestingly, the ductular reaction contributes partly to hepatocarcinogenesis of HPCs, and further, regenerating cholangiocytes after injury may be derived from hepatic stellate cells via mesenchymal to epithelia transition, a reverse phenomenon of type 2 EMT. Possible pathogenesis of type 2 EMT and its differences between renal and hepatic fibrosis are reviewed based on our experimental data.
\end{abstract}

Keywords: epithelial to mesenchymal transition; renal fibrosis; hepatic fibrosis; animal models; myofibroblasts; hepatic progenitor cells; bile ductular reaction

\section{Introduction}

Epithelial to mesenchymal transition (EMT), where epithelial cells lose their epithelial nature and gain mesenchymal characteristics, has been given much attention in the life science community [1]. The first description of possible EMT was proposed in 1982 [2]. Thus far, the pivotal roles of EMT have been seen in both physiological and pathological conditions; EMT plays roles in tissue modeling or remodeling $[3,4]$. EMT is basically classified into three types based on different biological settings with different functional consequences $[1,5]$. Type 1 EMT occurs during normal organogenesis; the generated immature mesenchymal cells form more mature epithelia via the mesenchymal to epithelial transition (MET); although type 1 is a converse phenomenon to EMT in pathological fibrosis, type 1 is important for investigating the other EMT in pathological settings (types 2 and 3), as mentioned below. Type $2 \mathrm{EMT}$ is associated with tissue repair responses such as fibrosis to underlying injuries in parenchymal organs. Type 2 EMT gives rise to myofibroblasts from epithelia to heal injured tissues; if the injury is mild and acute, the healing process is regarded as reparative fibrosis; on the contrary, in ongoing chronic inflammation, abnormal formation of myofibroblasts cause progressive fibrosis, thereafter leading to organ parenchymal destruction by excessive extra-cellular matrix (ECM) deposition. Type 3 EMT is related to malignancy, where neoplastic cells can migrate into surrounding tissues and invade at metastasis sites; this EMT occurs in carcinomas derived from epithelial cells, in which neoplastic epithelial cells are transformed into cells with mesenchymal nature. In all three types of EMT, there are various molecular events, including transcription factor activation, specific cell surface protein expression, reorganization of cytoskeletal proteins, production of ECM degradation 
enzymes and changes of specific microRNAs [1]. However, distinct differences governing the three distinct EMT types are not fully understood.

Over the last two decades, using human pathological tissues and experimental animal models, knowledge of EMT has accumulated. In this review, to shed some light on this subject, we focus on type 2 EMT in renal and hepatic fibrosis based on our experimental data using animal models. Basically, using cisplatin (CDDP)-induced rat renal fibrosis model, we have demonstrated further significance for EMT in renal fibrosis; in this animal model, possible participations of transforming growth factor- $\beta 1$ (TGF- $\beta 1$ ), platelet derived growth factor (PDGF)-BB, prostaglandins, osteopontin $(\mathrm{OPN})$, neutrophil gelatinase-associated lipocalin (NGAL) and bone morphogenic protein-6 (BMP-6) are discussed. For hepatic fibrosis, we used thioacetamide (TAA) to induce liver fibrosis/cirrhosis model, focusing on the relation between hepatic progenitor cells (HPCs) and EMT. In addition to TAA-induced hepatic cirrhosis, the roles of EMT were investigated in $\alpha$-naphthylisothiocyanate (ANIT)-induced rat biliary fibrosis occurring in the Glisson's sheath.

\section{Pathogenesis of Type 2 Epithelial to Mesenchymal Transition (EMT) in Renal Fibrosis}

\subsection{Renal Fibrosis and Disease Models}

Chronic kidney disease, characterized by extensive interstitial fibrosis, has become a major worldwide healthcare burden [6]. Irrespective of the etiology, renal fibrosis is the final common pathway of progressive kidney diseases [7]. Myofibroblasts, the cells morphologically and functionally intermediate between fibroblasts and smooth muscle cells, are the main source of excessive ECM deposition in renal fibrosis. Derivation of renal myofibroblasts may be heterogeneous; renal epithelia/endothelia, interstitial fibroblastic cells or mesenchymal pericytes have been proposed and, of these, the EMT process from injured renal epithelia is regarded as the most important pathway leading to formation of interstitial myofibroblasts in diseased kidneys at advanced stages [8-10]. Nephrogenesis consists of mutual induction of two cell populations derived from intermediate mesoderm: epithelial cells of the ureteric bud that grow out from the metanephric duct, and mesenchymal cells of the metanephric mesenchyme [11,12]. The Glomeruli and renal tubules, except collecting ducts are developmentally derived from the metanephric mesenchyme through MET (type 1 EMT) [13]. Injury to adult organs recapitulates embryonic programming in remodeling [14]. Thus, injured epithelia in chronic renal disease are thought to undergo regression to the metanephric mesenchymal phenotype and acquire myofibroblastic cell characteristics through EMT, showing reverse embryogenesis [15-17]. However, the significance of EMT in renal fibrosis is not fully understood [18], particularly on the formation of myofibroblastic cells via type 2 EMT.

Cultured tubular epithelial cell lines (such as NRK-52E) are frequently used to demonstrate type 2 EMT [19-22]. On the contrary, the occurrence of type 2 EMT in experimentally-induced renal failure models is inconsistent and, depending on the experimental conditions, some models are discovered to be EMT-prone and others EMT-resistant [23]. In unilateral ureteric obstruction (UUO) model, pressure-induced damage leads to progressive interstitial fibrosis via type 2 EMT phenomenon [24-27]. Renal fibrosis induced in rats by cisplatin (CDDP), a widely used anti-cancer drug with renal toxicity, is considered to be the best model of post-tubular injury fibrosis $[28,29]$. CDDP-induced renal lesions are characterized histopathologically by necrosis or desquamation of proximal renal epithelia and subsequent dilatation of the affected renal tubules $[29,30]$. The affected epithelia have the capacity of regeneration; however, completely damaged basal lamina causes incomplete regeneration leading to interstitial fibrosis via type 2 EMT, as abnormal regenerating renal epithelia show positive reaction to $\alpha$-smooth muscle actin ( $\alpha$-SMA), an immunophenotypical maker of myofibroblasts as mentioned below [30,31]. Compared to UUO models with frequent $\alpha$-SMA-positive renal epithelial cells, type 2 EMT in CDDP-induced rat renal fibrosis is less frequent; the pressure-induced damage tends to induce more frequently type 2 EMT in kidney lesions. 


\subsection{Expression of Type 2 EMT Markers}

During the process of type 2 EMT, cell-cell interactions of epithelia are lost with repressed tight junction proteins such as claudin and occludin, and then epithelia obtain the elongated migratory mesenchymal morphology of myofibroblasts [32]. Although the process is very complicated, the expression of cell surface protein such as cadherins and integrins is used to monitor type 2 EMT [33]; there is a downregulation of epithelial E-cadherin and upregulation of mesenchymal $N$-cadherin, so-called cadherin switch. Additionally, the expression of cytoskeletal markers, particularly $\alpha$-SMA, vimentin, desmin, fibroblast specific protein-1 (FSP-1) and $\beta$-catenin, has been evaluated to characterize renal tubular epithelia undergoing type 2 EMT $[5,34,35]$. Concomitant expression of both epithelial and mesenchymal markers indicates the presence of cells in the intermediate stages via type 2 EMT. $\alpha$-SMA, a component of actin cytoskeleton, is a well-accepted marker for completed myofibroblasts to identify the EMT process in injured renal epithelia [36,37]. Reorganization of $\alpha$-SMA-expressing cells undergoing EMT in both renal tubules and surrounding interstitial fibrotic areas may imply cell elongation and directional motility through disrupted basement membrane [32,38]. $\alpha$-SMA acts as stress fibers in myofibroblasts augmenting their contractile ability and migration, which is critical for tissue remodeling [33]. $\alpha$-SMA-positive myofibroblasts can produce ECMs such as collagens and fibronectin, culminating in renal interstitial fibrosis and then scar formation (contracted kidneys) [30,39].

In addition to $\alpha$-SMA, different cytoskeletal proteins expressed in myofibroblasts are regarded as useful markers for myofibroblast differentiation [30]. Vimentin has frequently been seen not only in type 2 EMT but also in type 3 EMT in carcinoma cells $[40,41]$ and desmin expression is seen in human and mouse podocytes after glomerular damage (type 2 EMT) [42]. Using CDDP- and UUO-induced rat fibrotic kidneys, we have demonstrated expression of $\alpha$-SMA and vimentin in both renal epithelia and interstitial cells, supporting the usefulness of these two markers to recognize type 2 EMT-undergoing cells [30]. Although interstitial myofibroblastic cells in spontaneous canine fibrotic kidneys expressed $\alpha$-SMA, epithelia in the fibrotic lesions did not show $\alpha$-SMA. However, vimentin expression was more strongly and frequently seen in both renal epithelia and interstitial cells in the fibrotic lesions of canine kidneys [30]. Desmin expression was seen only in interstitial myofibroblasts of CDDP-treated rat kidneys and epithelia of canine fibrotic kidneys, indicating that desmin is not always useful as a marker of EMT in both rat and canine fibrotic kidneys [30]. These results indicate interspecies heterogeneity of cytoskeletal immunoexpression, which should be considered when interpreting type 2 EMT of renal epithelia in fibrotic kidneys [30].

\subsection{Growth Factors Associated with Type 2 EMT}

Type 2 EMT is triggered by a variety of soluble factors. The most powerful factor is TGF- $\beta$ [43]. Out of three family members (TGF- $\beta 1,-\beta 2$, and $-\beta 3$ ), TGF- $\beta 1$ plays a critical role in type 2 EMT [44,45]. TGF- $\beta 1$ exerts its effect through either Smad or non-Smad pathway, and when added to cultured renal epithelial cell lines, the epithelia change from cuboidal to fusiform in shape and acquire myofibroblastic mesenchymal nature with repressed epithelial markers [32,46,47]. Similarly, we confirmed that a rat mesenchymal immature mesenchymal cell line MT-9 (with pericyte-like nature) and a porcine proximal renal epithelial cell line, LLC-PK1, showed a dose-dependent increment of $\alpha$-SMA after TGF- $\beta 1$ treatment [30]. In the same experiment, we illustrated that the addition of PDGF-BB, another fibrogenic factor [48], to the above cell lines increased the $\alpha$-SMA-positive cell number, although the $\alpha$-SMA expression degree was much less than that under TGF- $\beta 1$ treatment. Simultaneous addition of TGF- $\beta 1$ and PDGF-BB to LLC-PK1 showed a greater increment of $\alpha$-SMA-positive cell number than did the sole addition of TGF- $\beta 1$, indicating the additive effect of PDGF-BB in TGF- $\beta 1$-induced type 2 EMT. PDGF-BB may up-regulate TGF- $\beta 1$ synthesis with common signaling pathways, denoting a possible underlining mechanism for this augmentation [49]. Importance of TGF- $\beta 1$ has been reported in type 3 EMT in carcinomas, and that of PDGF-BB factor has been demonstrated in the induction of type 3 EMT in carcinoma and type 1 EMT in coronary smooth muscle differentiation [50-52]. PDGF-BB involvement in pericytes to myofibroblast conversion of type 2 is demonstrated in UUO and ischemic 
reperfusion injury in mouse kidneys [53]. In addition to TGF- $\beta 1$, collectively, studies on PDGF-BB on EMT would be beneficial to understand the molecular mechanisms behind renal type 2 EMT.

\subsection{Roles of Prostaglandins}

Prostaglandins, the lipid autacoids derived from arachidonic acid, play an important role in the pathophysiology of kidneys [54,55]. The factors influence the formation and loss of intercellular contacts in epithelial tissues [56], implying possible participation in type 2 EMT. Significant increment of prostaglandin E2 (PGE2) is observed in tubulointerstitial fibrosis induced by UUO [57-59]. PGE2 is the major prostanoid produced in the kidney and thought to influence cell proliferation and differentiation through its receptors, EP2 or EP4 [55,60,61]. PGE2 is synthesized by the conversion of arachidonic acid via cyclooxygenases (COX), COX-1 or COX-2, and terminal prostaglandin E synthases (PGES) [62,63]. Experiments using COX-1 and COX-2 deficient mice have indicated that COX-2 is essential for normal renal development, whereas no alterations were seen in renal structures of COX-1 deficient mice $[64,65]$. Cyclin D1, a factor of the G1 phase of the cell cycle, is important in cell cycle regulation [66]; its nuclear expression is seen in the G1 phase of the cell cycle and thereafter, the shift into cytoplasmic expression of cyclin D1 means transition to the $S$ phase $[67,68]$. In CDDP-induced rat renal fibrosis, we have shown participation of endogenous PGE2 in abnormal regeneration of renal tubular epithelia exclusively through EP4 where cyclin D1 expression was restricted within the nucleus of regenerating renal epithelial cells indicating G1 arrest. Interestingly, in the CDDP-induced rat renal fibrosis model, there was decreased COX-2 expression and increased COX-1 expression [69]. In nephrogenesis, in contrast, COX-2 expression is increased, accompanied by cyclin D1 expression both in the nucleus and cytoplasm of developing renal tubules [70]. These results indicate that, in addition to the importance of PGE2 in both normal and abnormal renal tubular development via EP4, COX-1 may play in more crucial roles in abnormal regeneration of renal tubules in CDDP-induced rat renal fibrosis. Although it is thought that the regeneration process of injured renal tubules is analogous to embryogenesis, these results indicate that there are differences between renal tubular development and regeneration of renal tubules; abnormal regeneration of injured renal tubules should be responsible for type 2 EMT. That is, incomplete regeneration of renal epithelial cells after renal damage can lead to progressive interstitial fibrosis, probably via EMT [31]. The addition of EP4 receptor agonist to cultured rat renal epithelial cell line, NRK-52E, reduces the expression of TGF- $\beta 1$-induced $\alpha$-SMA expression, indicating the inhibition of EMT [69]. Similar results were demonstrated using EP4 ${ }^{-/}$mice in vivo after UUO [59]. On the other hand, in a prostate carcinoma model, type 3 EMT was inhibited by EP4 antagonism [61]. These results indicate that the same molecule, EP4 (a receptor of PGE2), has different roles in type 2 and type 3 EMT.

\subsection{Neutrophil Gelatinase-Associated Lipocalin (NGAL), Osteopontin (OPN) and Bone Morphogenic Protein-6 (BMP-6)}

NGAL, a lipocalin superfamily protein, was first identified in activated neutrophils [71]. Later, its expression was identified in epithelia in inflammatory lesions and in malignancy [72]. NGAL expression is upregulated after damaged renal epithelia; therefore, its expression is regarded as a promising tubular biomarker in the diagnostics of acute kidney diseases, both in clinical and experimental settings [73-75]. OPN is an acidic glycoprotein synthesized in bone and various epithelial tissues; its expression is limited in the loop of Henle and distal tubules of normal rat kidneys, whereas the upregulated expression is seen in all renal tubule segments after renal injury [76,77]. OPN has multifunctional roles in bone morphogenesis, macrophage infiltration and tumorigenesis [77,78]. In CDDP-induced rat renal fibrosis, NGAL expression was seen in completely regenerating proximal renal tubules with regularly arranged epithelial cells, correlating well with proliferating activity. Interestingly, OPN expression was seen in dilated or atrophied abnormal renal tubules surrounded by flattened or irregularly-arranged epithelia, around which interstitial fibrosis was taking place; the increased expression of OPN significantly correlated with $\alpha$-SMA-positive myofibroblast appearance, expression of TGF- $\beta 1 \mathrm{mRNA}$ and CD68-positive macrophages [79,80]. Treatment of NRK-52E with TGF- $\beta 1$ decreased NGAL expression, whereas OPN expression was increased; furthermore, 
$E$-cadherin was decreased but $\alpha$-SMA expression was increased. It is considered that NGAL is involved in favorable regeneration of renal tubules after injury, whereas OPN expressing in incomplete regeneration of renal epithelia participates in renal progressive fibrosis via type 2 EMT. In fact, the addition of OPN to NRK-52E induces EMT [81]. However, there is a report describing that NGAL may participate in type 3 EMT in carcinoma with metastasis [82,83], an opposite phenomenon to type 2 EMT in renal fibrosis.

BMP-6 is a member of TGF- $\beta$ superfamily [84]. Generally, it is known that the TGF- $\beta$ superfamily plays pivotal roles in renal fibrosis by antagonizing TGF- $\beta$-induced pro-fibrogenic signaling [85]. TGF- $\beta$ exerts its functions mainly through its down stream signaling molecules, Smads 2 and 3 [86]. Particularly, the anti-fibrotic effect of BMP-7 is well documented and has been given attention as a possible therapeutic target [87-89]. BMP-7 has an inhibitory action, particularly on Smad 3 [90], and exerts its effects by reducing ECM deposition by inactivating ECM-producing myofibroblasts and EMT, and by enhancing ECM degradation [91]. Similarly, BMP-6 deficiency aggravate interstitial damage and fibrosis in UUO mouse model independent of BMP-7 [92]. In CDDP-induced rat renal fibrosis, BMP-6 expression was seen in abnormal renal epithelial cells and also in peri-tubular myofibroblasts in CDDP-induced rat renal fibrosis [80]. The addition of TGF- $\beta 1$ to NRK-52E increased expression of BMP-6; on the contrary, BMP-6 treatment decreased TGF- $\beta 1$ expression of NRK-52E cells. BMP- 6 has an anti-fibrotic effect by the inhibition of TGF- $\beta 1$ activity by suppressing TGF- $\beta 1$-induced JNK activation and Smad signaling [93]. Additionally, it might have a direct role on TGF- $\beta 1$ functions. Besides BMP-7, BMP-6 would be another possible therapeutic tool [93]. Taken together, the possible participation of type 2 EMT in kidney fibrosis is shown in Scheme 1.

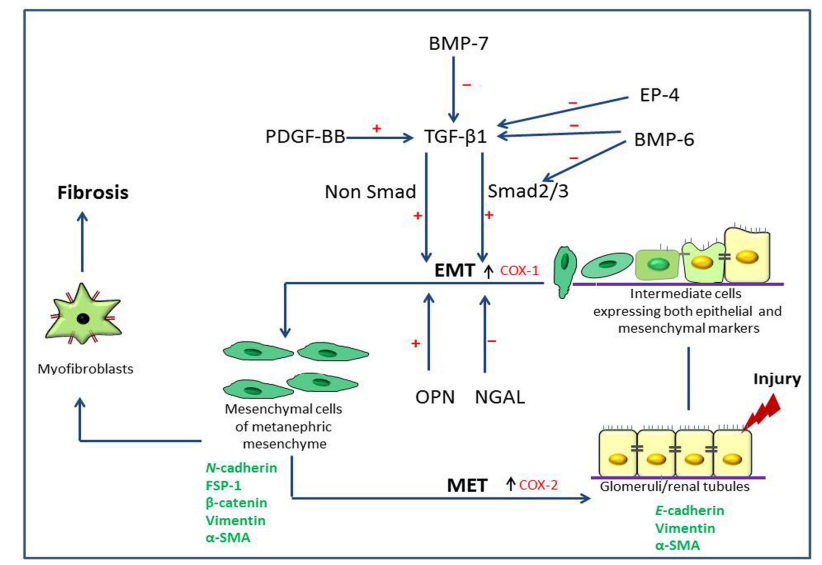

Scheme 1. Possible epithelial to mesenchymal transition mechanisms of renal fibrosis. Mesenchymal cells of metanephric mesenchyme give rise to renal epithelial cells during embryogenesis through the mesenchymal to epithelial transition (MET), and these cells express epithelial markers such as $E$-cadherin and mesenchymal cell markers such as vimentin and $\alpha$-smooth muscle actin ( $\alpha$-SMA). After injury, renal epithelial cells undergo phenotypical changes through the epithelial to mesenchymal transition (EMT, type 2), in which they acquire intermediate phenotypes expressing both epithelial and mesenchymal markers; they further transform into mesenchymal cells (expressing mesenchymal markers such as $N$-cadherin, fibroblast specific protein-1 (FSP-1), $\beta$-catenin, vimentin and $\alpha$-SMA). EMT is considered the reverse embryogenesis of MET. Finally, these mesenchymal cells become myofibroblasts which are responsible for progressive renal fibrosis. During the MET process, there is an increment of cyclooxygenase (COX)-2, whereas during EMT, COX-1 increases. Transforming growth factor- $\beta 1$ (TGF- $\beta 1$ ) generated via non-Smad and Smad pathways stimulates the EMT in renal fibrosis. Platelet derived growth factor-BB (PDGF-BB) has an additive effect on the TGF- $\beta 1$-induced EMT. Prostaglandin receptor 4 (EP4), bone morphogenic protein-6 (BMP-6) and neutrophil gelatinase-associated lipocalin (NGAL) have inhibitory effects on type 2 EMT. Bone morphogenic protein-7 (BMP-7) counteracts TGF- $\beta 1$-induced EMT [94]. (+, stimulation; - , inhibition; $\uparrow$, increment). 
Apart from TGF- $\beta 1$, studying the roles of PDGF-BB on the induction of EMT would be beneficial to understand the underling molecular mechanisms of renal type 2 EMT. Further studies on the dual roles of EP4 and NGAL between type 2 (favorable effects) and type 3 EMT (negative effects) would lead to better understanding the underscoring mechanisms governing different types of EMT. BMP- 6 and BMP-7 might emerge as a possible new therapeutic tool to improve progressive renal fibrosis.

\section{Pathogenesis of Type 2 Epithelial to Mesenchymal Transition (EMT) in Hepatic Fibrosis}

\subsection{Liver Fibrosis and Disease Models}

Irrespective of the cause, dysregulated wound healing response in the liver with excessive ECM deposition results in progressive cirrhosis, which is characterized by the formation of regenerative and degenerative nodules (pseudolobules) separated by fibrous septa [95-97]. Liver has a massive regenerating capability after injury with restoring its lost mass and adjusting the size to that of the organism [98]. Despite this fascinating ability of regeneration, liver cirrhosis has become a leading cause of death worldwide. Hepatitis B and C viral infection, auto-immune diseases, alcohol abuse and metabolic diseases such as non-alcoholic fatty liver disease and non-alcoholic steatohepatitis (NASH) are causes of hepatic cirrhosis [99-101]. Additionally, hepatic cirrhosis has become a main cause of hepatocellular carcinoma. To study hepatic cirrhosis, various animal models have been utilized [102]. We have used toxin-induced rat models: thioacetamide (TAA)-induced and $\alpha$-naphthylisothiocyanate (ANIT)-induced hepatic fibrosis; the former develops centrilobular injury/necrosis and subsequent fibrosis, the latter induced peri-biliary fibrosis in the Glisson' sheath $[103,104]$. The TAA-induced rat hepatic cirrhosis, induced by repeated injections, bears a close resemblance to human micro-nodular cirrhosis $[96,105,106]$. ANIT injection to rats damages bile duct epithelial cells, thereby producing intrahepatic cholestasis, bile duct hyperplasia (bile duct reaction) and peri-biliary fibrosis [107-109].

\subsection{Possible Liver EMT in Thioacetamide (TAA)-Induced Rat Cirrhosis}

After transient tissue injury, reparative fibrosis occurs, whereas persistent and repeated damage induces progressive fibrosis, leading to cirrhosis. The fibrotic lesions is characterized by deposition of ECM produced by myofibroblasts [99]. Hepatic myofibroblasts are heterogeneous in origin and nature. Quiescent hepatic stellate cells (HSCs) are considered to be the major source of hepatic myofibroblasts. Additionally, bone marrow stem cells, pre-existing fibroblasts and mesenchymal cells via type 2 EMT of hepatocytes or bile duct epithelia have been proposed as other derivation of hepatic myofibroblasts [110,111]. However, EMT as a source of hepatic myofibroblasts is highly controversial [112-114]. TGF- $\beta 1$-treated mouse hepatocytes showed downregulation of $E$-cadherin and upregulation of mesenchymal marker (such as vimentin) and type I collagen synthesis, indicating possible EMT in vitro [115]. In vivo evidence for hepatocyte EMT was illustrated by Zeisberg and colleagues using a double transgenic mouse model where hepatocytes that undergo EMT contribute to the FSP1-positive fibroblasts in carbon tetrachloride-induced liver fibrosis [116]. In addition to hepatocytes, biliary epithelia could give rise to hepatic myofibroblasts through type 2 EMT. Evidence for biliary epithelia EMT was shown in a bile duct ligation (BDL)-induced mouse hepatic fibrosis [117], and possible contribution of cholangiocytes to fibrosis via type 2 EMT was demonstrated in vitro [118]. The co-localization of CK19 (a marker of bile ductular cells) and mesenchymal markers such as FSP-1 and vimentin has been demonstrated in samples of human biliary atresia and in cultures of hepatic progenitor cells (HPCs) [119,120]. HPCs are cells capable of differentiating into hepatocytes and bile duct epithelia. Proliferation and expansion of HPCs located in the canals of Herring, so-called "ductular reaction", always occurs in the vicinity of myofibroblasts in fibrotic lesions, indicating possible involvement of type 2 EMT of HPCs [121-123]. In studies using TAA-induced rat liver cirrhosis, we observed HPC-related bile duct reactions depended on progressive fibrosis. Expression of glial fibrillary acidic protein (GFAP) (a marker for activated HSCs/hepatic myofibroblasts) and cytokeratin 19 (CK19) (a marker for bile duct cells and HPCs) was observed simultaneously in reacting 
bile duct cells and HPCs [103]. Additionally, GFAP-expressing myofibroblasts in rat cirrhotic livers were present, raising the possibility of type 2 EMT either via bile duct cells or HPCs. In contrast to observation by Xia and coworkers in BDL-mouse model [117], however, no co-expression of $\alpha$-SMA (the well accepted hepatic myofibroblast marker) and CK19 was observed in reacting bile duct cells and HPCs in TAA-induced rat cirrhosis; furthermore, there was no cadherin switch (from $E$-cadherin to $\mathrm{N}$-cadherin) in these ductular cells with progressive cirrhosis. There was also no immunohistochemical evidence for type 2 EMT. Recapitulation of embryogenesis in fibrosis is a key indication for type 2 EMT. In the kidney, tubular epithelium is of mesodermal origin derived from intermediate mesoderm via MET (type 1 EMT). Therefore, renal tubular epithelia could retain their mesenchymal imprints and return easily to a mesenchymal state via type 2 EMT during renal fibrosis after injury. On the other hand, in the liver, all the epithelia are derived from the foregut endoderm [1,124]; therefore it is unlikely to revert to a mesenchymal phenotype via type 2 EMT during hepatic fibrogenesis.

\subsection{Importance of Ductal Reaction and Possible Hepatocarcinogenesis, Instead of Type 2 EMT, in TAA-Induced Rat Cirrhosis}

As mentioned above, type 2 EMT of bile ducts or HPCs is very unlikely. Interestingly, it is thought that the ductular reaction in hepatic cirrhosis is a recapitulation of hepatic ontogenesis [125]. The ductal plate, generated from the embryonic precursor cells, remodels to form intrahepatic bile ducts and periportal hepatocytes during embryogenesis [126]. The remnants of the ductal plate give rise to the canals of Herring in adult liver, of which cells produce bi-potential HPCs in liver lesions [127]. Particularly, in cirrhotic liver, this cell compartment expands, forming ductular reaction; although such event is regarded as an effort to restore the normal hepatic architecture, novel hepatocytes and bile duct cells are developed as the result. In TAA-induced rat hepatic cirrhosis, the analysis of gene profiles related to ductular reaction by laser microdissection demonstrated higher expression of TGF- $\beta 1$ and PDGF- $\beta$ mRNA in the HPC locality [103]. These factors. upregulated in ductal epithelia. have shown to activate transition of surrounding HSCs to hepatic myofibroblasts, leading to hepatic fibrosis [123]. The intimate association of HPCs and myofibroblasts in cirrhotic livers is not related to type 2 EMT phenomenon. Additionally, we have showed that, in TAA-induced rat cirrhosis, there was greater mRNA expression of both Wnt2 and Wnt4 which act via canonical and non-canonical Wnt signaling pathways, respectively; furthermore, increased expression of Glypican-3, which belongs to the family of heparan sulfate proteoglycans and is reported to promote the growth of hepatocellular carcinoma [128,129], was seen [103]. The Wnt/ $\beta$-catenin pathway is also involved not only in liver embryogenesis but also in activation of tumorigenic HPCs [130]. Because HPCs are thought to be a possible precursor of hepatocellular carcinomas, the increased expression of these genes in ductular reaction the vicinity of HPCs may imply possible development of hepatocellular carcinomas at the advanced stages of hepatic cirrhosis probably via maturation arrest of HPCs [131]. In hepatic cirrhosis, the bile duct reaction (ductular reaction), which are derived from HPCs, should be considered to have different roles in tumorigenesis, although the bile duct reaction may be related partly to type 2 EMT leading to progressive fibrosis [132-134].

It is worth mentioning that the immunohistochemical method of concomitant expression of both epithelial and mesenchymal markers has limitations in investigating type 2 EMT in hepatic cirrhosis. Mesenchymal cells are dynamic in their phenotype, and the transforming epithelial cells might not yet have fully activated the expression of mesenchymal genes $[3,135]$. Therefore, there are somewhat difficulties in observing a transient event of cells both expressing epithelial and mesenchymal markers. Lineage tracing experiments could be beneficial; however, such experiments using different animal hepatic fibrosis models did not demonstrate clear evidence of type 2 EMT of cholangiocytes [136]. 
3.4. Regenerating Cholangiocytes Do Not Induce Type 2 EMT in $\alpha$-Naphthylisothiocyanate (ANIT)-Induced Peri-Biliary Fibrosis

We considered that peri-biliary fibrosis would be more useful for investigating type 2 EMT. As mentioned above, injection of ANIT in rats can induce peri-biliary fibrosis after cholangiocyte injury. In this ANIT-induced peri-biliary fibrosis, regenerating cholangiocytes after injury showed positive reaction to vimentin and nestin (a type VI intermediate filament protein expressed mainly by neuronal stem cells), in addition to CK19 expression [104]. However, dual reactions reacting to CK19 and $\alpha$-SMA were not seen in ANIT-induced peri-biliary fibrosis. These findings denied that regenerating cholangiocytes are associated with type 2 EMT. Interestingly, HSCs expressed nestin. Therefore, co-expression of CK19 and nestin in regenerating cholangiocytes in the peri-biliary fibrosis may indicate that HSCs are a possible progenitor of repopulating cholangiocytes after injury. The possible differentiation of HSCs to hepatocytes has been reported [137,138]. Nestin could have a role in the migration of cholangiocyte progenitors, perhaps from nestin-positive HSCs in the periportal area or vimentin/nestin-positive connective tissue cells in the Glisson's sheath [104]. Reactivity for Ki67, a marker of cellular proliferation, in HSCs co-expressing nestin, vimentin and CK19 indicates that subpopulation of HSCs might differentiate into cholangiocytes by the migration $[104,138]$. Hence, in ANIT-induced peri-biliary fibrosis, nestin-expressing mesenchymal HSCs may be possible progenitor of repopulating cholangiocytes, indicating the MET; this EMT may be a reverse phenomenon of type 2 EMT [104].

\subsection{Type 2 EMT and Hepatic Cirrhosis}

In TAA-induced cirrhosis and ANIT-induced peri-biliary fibrosis, collectively, there was no clear evidence of type 2 EMT via biliary epithelia or HPCs. However, we showed that ductal reaction in TAA-induced cirrhosis may be related to possible hepatocarcinogenesis of HPCs, and that regenerating cholangiocytes in ANIT-induced peri-biliary fibrosis may be derived from HSCs via MET, a reverse phenomenon of type 2 EMT (Scheme 2).

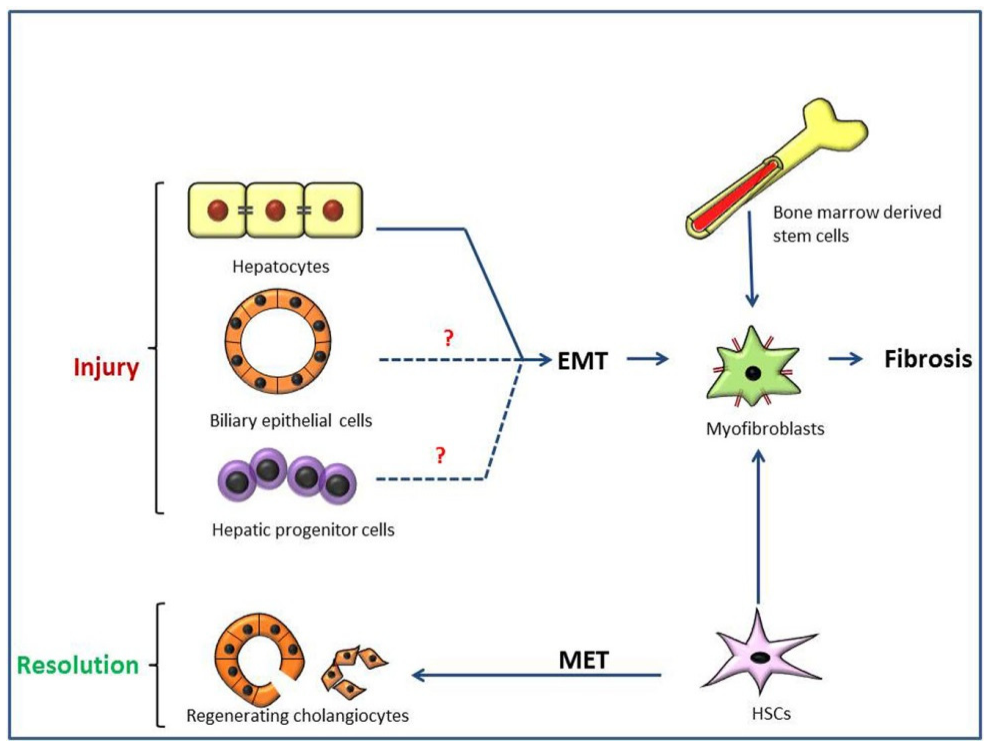

Scheme 2. Possible epithelial to mesenchymal transition (EMT) mechanisms of liver fibrosis. Hepatic stellate cells (HSCs), bone marrow-derived stem cells and mesenchymal cells via type 2 EMT from hepatocytes, biliary epithelial cells or hepatic progenitor cells are depicted as the possible sources of myofibroblasts in progressive liver fibrosis (cirrhosis) [110,111,116,117,121-123]. The experiments focusing on EMT of biliary epithelia and hepatic progenitor cells show no evidence supporting the process. However, in the resolution phase of biliary fibrosis, HSCs could undergo mesenchymal to epithelial transition (MET), giving rise to regenerating cholangiocytes. (?, inconclusive evidences). 


\section{Conclusions}

EMT is a critical process that occurs both in normal development as well as in pathological settings. In this review, we focused on type 2 EMT, which is related to renal and hepatic fibrosis. There were differences in significance and occurrence of type 2 EMT-related fibrosis between the kidney and liver. It is worth exploring the underlying molecular mechanisms to find any differences. Furthermore, comparing different types of EMT (types 1,2 and 3) would lead to better understanding of EMT, a unique phenomenon of the body. Progressive fibrosis in the kidney and liver is an intractable disease. The clarification of the pathogenesis of type 2 EMT would provide very useful information for possible therapies and expanding knowledge on stem cell biology would open up novel dimensions in understanding the process.

Acknowledgments: This work was supported partly by the captioned research program funded by Food Safety Commission Japan (FSCJ) (2014), by Kobayashi International Scholarship Foundation (2014-2015) and by JSPS KAKENHI Grant Number 26292152.

Conflicts of Interest: The authors declare no conflict of interest.

\section{References}

1. Kalluri, R.; Weinberg, R.A. The basics of epithelial-mesenchymal transition. J. Clin. Investig. 2009, 119, 1420-1428. [CrossRef] [PubMed]

2. Greenburg, G.; Hay, E.D. Epithelia suspended in collagen gels can lose polarity and express characteristics of migrating mesenchymal cells. J. Cell Biol. 1982, 95, 333-339. [CrossRef] [PubMed]

3. Choi, S.S.; Diehl, A.M. Epithelial-to-mesenchymal transitions in the liver. Hepatology 2009, 50, $2007-2013$. [CrossRef] [PubMed]

4. Kothari, A.N.; Mi, Z.; Zapf, M.; Kuo, P.C. Novel clinical therapeutics targeting the epithelial to mesenchymal transition. Clin. Transl. Med. 2014, 3, 35. [CrossRef] [PubMed]

5. Zeisberg, M.; Neilson, E.G. Biomarkers for epithelial-mesenchymal transitions. J. Clin. Investig. 2009, 119, 1429-1437. [CrossRef] [PubMed]

6. Faa, G.; Sanna, A.; Gerosa, C.; Fanni, D.; Puddu, M.; Ottonello, G.; van Eyken, P.; Fanos, V. Renal physiological regenerative medicine to prevent chronic renal failure: Should we start at birth? Clin. Chim. Acta 2015, 444, 156-162. [CrossRef] [PubMed]

7. Cook, H.T. The origin of renal fibroblasts and progression of kidney disease. Am. J. Pathol. 2010, 176, $22-24$. [CrossRef] [PubMed]

8. Liu, Y. Epithelial to mesenchymal transition in renal fibrogenesis: Pathologic significance, molecular mechanism, and therapeutic intervention. J. Am. Soc. Nephrol. 2004, 15. [CrossRef]

9. Kim, M.-K.; Maeng, Y.-I.; Sung, W.J.; Oh, H.-K.; Park, J.-B.; Yoon, G.S.; Cho, C.-H.; Park, K.-K. The differential expression of TGF- $\beta 1$, ILK and wnt signaling inducing epithelial to mesenchymal transition in human renal fibrogenesis: An immunohistochemical study. Int. J. Clin. Exp. Pathol. 2013, 6, 1747-1758. [PubMed]

10. Fintha, A.; Gasparics, Á.; Fang, L.; Erdei, Z.; Hamar, P.; Mózes, M.M.; Kökény, G.; Rosivall, L.; Sebe, A. Characterization and role of SCAI during renal fibrosis and epithelial-to-mesenchymal transition. Am. J. Pathol. 2013, 182, 388-400. [CrossRef] [PubMed]

11. Hendry, C.; Rumballe, B.; Moritz, K.; Little, M.H. Defining and redefining the nephron progenitor population. Pediatr. Nephrol. 2011, 26, 1395-1406. [CrossRef] [PubMed]

12. Kopan, R.; Cheng, H.-T.; Surendran, K. Molecular insights into segmentation along the proximal distal axis of the nephron. J. Am. Soc. Nephrol. 2007, 18, 2014-2020. [CrossRef] [PubMed]

13. Horster, M.F.; Braun, G.S.; Huber, S.M. Embryonic renal epithelia: Induction, nephrogenesis, and cell differentiation. Physiol. Rev. 1999, 79, 1157-1191. [PubMed]

14. Fabian, S.L.; Humphreys, B.D. What's past is prologue: Developmental pathways and chronic allograft dysfunction. Am. J. Transpl 2012, 12, 5-6. [CrossRef] [PubMed]

15. Swetha, G.; Chandra, V.; Phadnis, S.; Bhonde, R. Glomerular parietal epithelial cells of adult murine kidney undergo EMT to generate cells with traits of renal progenitors. J. Cell. Mol. Med. 2011, 15, 396-413. [PubMed] 
16. Yuasa, T.; Izawa, T.; Kuwamura, M.; Yamate, J. Thy-1 expressing mesenchymal cells in rat nephrogenesis in correlation with cells immunoreactive for $\alpha$-smooth muscle actin and vimentin. J. Toxicol. Pathol. 2010, 23. [CrossRef] [PubMed]

17. El-Nahas, A.M. Plasticity of kidney cells: Role in kidney remodeling and scarring. Kidney Int. 2003, 64, 1553-1563. [CrossRef] [PubMed]

18. Liu, Y. New insights into epithelial-mesenchymal transition in kidney fibrosis. J. Am. Soc. Nephrol. 2010, 21, 212-222. [CrossRef] [PubMed]

19. Runyan, C.E.; Hayashida, T.; Hubchak, S.; Curley, J.F.; Schnaper, H.W. Role of SARA (SMAD anchor for receptor activation) in maintenance of epithelial cell phenotype. J. Biol. Chem. 2009, 284, 25181-25189. [CrossRef] [PubMed]

20. Zaza, G.; Masola, V.; Granata, S.; Bellin, G.; dalla Gassa, A.; Onisto, M.; Gambaro, G.; Lupo, A. Sulodexide alone or in combination with low doses of everolimus inhibits the hypoxia-mediated epithelial to mesenchymal transition in human renal proximal tubular cells. J. Nephrol. 2015, 28, 431-440. [CrossRef] [PubMed]

21. Tan, T.K.; Zheng, G.; Hsu, T.-T.; Wang, Y.; Lee, V.W.S.; Tian, X.; Wang, Y.; Cao, Q.; Wang, Y.; Harris, D.C.H. Macrophage matrix metalloproteinase-9 mediates epithelial-mesenchymal transition in vitro in murine renal tubular cells. Am. J. Pathol. 2010, 176, 1256-1270. [CrossRef] [PubMed]

22. Zeisberg, M.; Bonner, G.; Maeshima, Y.; Colorado, P.; Müller, G.A.; Strutz, F.; Kalluri, R. Renal fibrosis: Collagen composition and assembly regulates epithelial-mesenchymal transdifferentiation. Am. J. Pathol. 2001, 159, 1313-1321. [CrossRef]

23. Inoue, T.; Umezawa, A.; Takenaka, T.; Suzuki, H.; Okada, H. The contribution of epithelial-mesenchymal transition to renal fibrosis differs among kidney disease models. Kidney Int. 2015, 87, 233-238. [CrossRef] [PubMed]

24. Chevalier, R.L.; Forbes, M.S.; Thornhill, B.A. Ureteral obstruction as a model of renal interstitial fibrosis and obstructive nephropathy. Kidney Int. 2009, 75, 1145-1152. [CrossRef] [PubMed]

25. Yuan, Y.; Zhang, F.; Wu, J.; Shao, C.; Gao, Y. Urinary candidate biomarker discovery in a rat unilateral ureteral obstruction model. Sci. Rep. 2015, 5, 9314. [CrossRef] [PubMed]

26. Ucero, A.C.; Benito-Martin, A.; Izquierdo, M.C.; Sanchez-Niño, M.D.; Sanz, A.B.; Ramos, A.M.; Berzal, S.; Ruiz-Ortega, M.; Egido, J.; Ortiz, A. Unilateral ureteral obstruction: Beyond obstruction. Int. Urol. Nephrol. 2014, 46, 765-776. [CrossRef] [PubMed]

27. Lan, A.; Zhang, J.; Xiao, Z.; Peng, X.; Qi, Y.; Du, J. Akt2 is involved in loss of epithelial cells and renal fibrosis following unilateral ureteral obstruction. PLoS ONE 2014, 9, e105451. [CrossRef] [PubMed]

28. Yamate, J.; Tatsumi, M.; Nakatsuji, S.; Kuwamura, M.; Kotani, T.; Sakuma, S. Immunohistochemical observations on the kinetics of macrophages and myofibroblasts in rat renal interstitial fibrosis induced by cis-diamminedichloroplatinum. J. Comp. Pathol. 1995, 112, 27-39. [CrossRef]

29. Yamate, J.; Ishida, A.; Tsujino, K.; Tatsumi, M.; Nakatsuji, S.; Kuwamura, M.; Kotani, T.; Sakuma, S. Immunohistochemical study of rat renal interstitial fibrosis induced by repeated injection of cisplatin, with special reference to the kinetics of macrophages and myofibroblasts. Toxicol. Pathol. 1996, 24, 199-206. [CrossRef] [PubMed]

30. Yamate, J.; Kuribayashi, M.; Kuwamura, M.; Kotani, T.; Ogihara, K. Differential immunoexpressions of cytoskeletons in renal epithelial and interstitial cells in rat and canine fibrotic kidneys, and in kidney-related cell lines under fibrogenic stimuli. Exp. Toxicol. Pathol. 2005, 57, 135-147. [CrossRef] [PubMed]

31. Yamate, J.; Sato, K.; Machida, Y.; Ide, M.; Sato, S.; Nakatsuji, S.; Kuwamura, M.; Kotani, T.; Sakuma, S. Cisplatin-Induced rat renal interstitial fibrasis; a possible pathogenesis based on the data. J. Toxicol. Pathol. 2000, 13, 237-247. [CrossRef]

32. Lamouille, S.; Xu, J.; Derynck, R. Molecular mechanisms of epithelial-mesenchymal transition. Nat. Rev. Mol. Cell Biol. 2014, 15, 178-196. [CrossRef] [PubMed]

33. Scanlon, C.S.; van Tubergen, E.A.; Inglehart, R.C.; D'Silva, N.J. Biomarkers of epithelial-mesenchymal transition in squamous cell carcinoma. J. Dent. Res. 2012, 92, 114-121. [CrossRef] [PubMed]

34. Pinzani, M. Epithelial-mesenchymal transition in chronic liver disease: Fibrogenesis or escape from death? J. Hepatol. 2011, 55, 459-465. [CrossRef] [PubMed] 
35. Roeder, S.S.; Stefanska, A.; Eng, D.G.; Kaverina, N.V.; Sunseri, M.W.; McNicholas, B.A.; Rabinovitch, P.; Engel, F.B.; Daniel, C.; Amann, K.; et al. Changes in glomerular parietal epithelial cells in mouse kidneys with advanced age. Am. J. Physiol. Renal Physiol. 2015, 309, F164-F178. [CrossRef] [PubMed]

36. Hinz, B.; Phan, S.H.; Thannickal, V.J.; Galli, A.; Bochaton-Piallat, M.-L.; Gabbiani, G. The myofibroblast: One function, multiple origins. Am. J. Pathol. 2007, 170, 1807-1816. [CrossRef] [PubMed]

37. Otranto, M.; Sarrazy, V.; Bonté, F.; Hinz, B.; Gabbiani, G.; Desmoulière, A. The role of the myofibroblast in tumor stroma remodeling. Cell Adh. Migr. 2012, 6, 203-219. [CrossRef] [PubMed]

38. Thiery, J.P.; Sleeman, J.P. Complex networks orchestrate epithelial-mesenchymal transitions. Nat. Rev. Mol. Cell Biol. 2006, 7, 131-142. [CrossRef] [PubMed]

39. Masszi, A.; Fan, L.; Rosivall, L.; McCulloch, C.A.; Rotstein, O.D.; Mucsi, I.; Kapus, A. Integrity of cell-cell contacts is a critical regulator of TGF- $\beta$ 1-induced epithelial-to-myofibroblast transition: Role for $\beta$-catenin. Am. J. Pathol. 2004, 165, 1955-1967. [CrossRef]

40. Wu, S.; Liu, S.; Liu, Z.; Huang, J.; Pu, X.; Li, J.; Yang, D.; Deng, H.; Yang, N.; Xu, J. Classification of circulating tumor cells by epithelial-mesenchymal transition markers. PLoS ONE 2015, 10, e0123976. [CrossRef] [PubMed]

41. Yang, J.; Mani, S.A.; Donaher, J.L.; Ramaswamy, S.; Itzykson, R.A.; Come, C.; Savagner, P.; Gitelman, I.; Richardson, A.; Weinberg, R.A. Twist, a master regulator of morphogenesis, plays an essential role in tumor metastasis. Cell 2004, 117, 927-939. [CrossRef] [PubMed]

42. Li, Y.; Kang, Y.S.; Dai, C.; Kiss, L.P.; Wen, X.; Liu, Y. Epithelial-to-mesenchymal transition is a potential pathway leading to podocyte dysfunction and proteinuria. Am. J. Pathol. 2008, 172, 299-308. [CrossRef] [PubMed]

43. O'Connor, J.W.; Gomez, E.W. Biomechanics of TGF $\beta$-induced epithelial-mesenchymal transition: Implications for fibrosis and cancer. Clin. Transl. Med. 2014, 3, 23. [CrossRef] [PubMed]

44. Kasai, H.; Allen, J.T.; Mason, R.M.; Kamimura, T.; Zhang, Z. TGF- $\beta 1$ induces human alveolar epithelial to mesenchymal cell transition (EMT). Respir. Res. 2005, 6, 56. [CrossRef] [PubMed]

45. Iwano, M. EMT and TGF- $\beta$ in renal fibrosis. Front. Biosci. 2010, S2, 229-238. [CrossRef]

46. O'Connor, J.W.; Gomez, E.W. Cell adhesion and shape regulate TGF- $\beta 1$-induced epithelial-myofibroblast transition via MRTF-A signaling. PLoS ONE 2013, 8, e83188. [CrossRef] [PubMed]

47. Xu, J.; Lamouille, S.; Derynck, R. TGF- $\beta$-induced epithelial to mesenchymal transition. Cell Res. 2009, 19, 156-172. [CrossRef] [PubMed]

48. Tang, W.W.; Ulich, T.R.; Lacey, D.L.; Hill, D.C.; Qi, M.; Kaufman, S.A.; Van, G.Y.; Tarpley, J.E.; Yee, J.S. Platelet-derived growth factor-BB induces renal tubulointerstitial myofibroblast formation and tubulointerstitial fibrosis. Am. J. Pathol. 1996, 148, 1169-1180. [PubMed]

49. Kordes, C.; Brookmann, S.; Häussinger, D.; Klonowski-Stumpe, H. Differential and synergistic effects of platelet-derived growth factor-BB and transforming growth factor- $\beta 1$ on activated pancreatic stellate cells. Pancreas 2005, 31, 156-167. [CrossRef] [PubMed]

50. Su, A.; He, S.; Tian, B.; Hu, W.; Zhang, Z. MicroRNA-221 mediates the effects of PDGF-BB on migration, proliferation, and the epithelial-mesenchymal transition in pancreatic cancer cells. PLoS ONE 2013, 8, e71309. [CrossRef] [PubMed]

51. Lu, J.; Landerholm, T.E.; Wei, J.S.; Dong, X.R.; Wu, S.P.; Liu, X.; Nagata, K.; Inagaki, M.; Majesky, M.W. Coronary smooth muscle differentiation from proepicardial cells requires rhoA-mediated actin reorganization and p160 rho-kinase activity. Dev. Biol. 2001, 240, 404-418. [CrossRef] [PubMed]

52. Andrae, J.; Gallini, R.; Betsholtz, C. Role of platelet-derived growth factors in physiology and medicine. Genes Dev. 2008, 22, 1276-1312. [CrossRef] [PubMed]

53. Chen, Y.-T.; Chang, F.-C.; Wu, C.-F.; Chou, Y.-H.; Hsu, H.-L.; Chiang, W.-C.; Shen, J.; Chen, Y.-M.; Wu, K.-D.; Tsai, T.-J.; et al. Platelet-derived growth factor receptor signaling activates pericyte-myofibroblast transition in obstructive and post-ischemic kidney fibrosis. Kidney Int. 2011, 80, 1170-1181. [CrossRef] [PubMed]

54. Breyer, M.D.; Breyer, R.M. Prostaglandin E receptors and the kidney. Am. J. Physiol. Renal Physiol. 2000, 279, F12-F23. [PubMed]

55. Ricciotti, E.; FitzGerald, G.A. Prostaglandins and inflammation. Arterioscler. Thromb. Vasc. Biol. 2011, 31, 986-1000. [CrossRef] [PubMed]

56. Menter, D.G.; Dubois, R.N. Prostaglandins in cancer cell adhesion, migration, and invasion. Int. J. Cell Biol. 2012, 2012, 723419. [CrossRef] [PubMed] 
57. Okegawa, T.; Jonas, P.E.; DeSchryver, K.; Kawasaki, A.; Needleman, P. Metabolic and cellular alterations underlying the exaggerated renal prostaglandin and thromboxane synthesis in ureter obstruction in rabbits. Inflammatory response involving fibroblasts and mononuclear cells. J. Clin. Investig. 1983, 71, 81-90. [CrossRef] [PubMed]

58. Whinnery, M.A.; Shaw, J.O.; Beck, N. Thromboxane B2 and prostaglandin E2 in the rat kidney with unilateral ureteral obstruction. Am. J. Physiol. 1982, 242, F220-F225. [PubMed]

59. Nakagawa, N.; Yuhki, K.; Kawabe, J.; Fujino, T.; Takahata, O.; Kabara, M.; Abe, K.; Kojima, F.; Kashiwagi, H.; Hasebe, N.; et al. The intrinsic prostaglandin E2-EP4 system of the renal tubular epithelium limits the development of tubulointerstitial fibrosis in mice. Kidney Int. 2012, 82, 158-171. [CrossRef] [PubMed]

60. Tang, L.; Loutzenhiser, K.; Loutzenhiser, R. Biphasic actions of prostaglandin E2 on the renal afferent arteriole: Role of EP3 and EP4 receptors. Circ. Res. 2000, 86, 663-670. [CrossRef] [PubMed]

61. Kim, H.N.; Narayanan, N.K.; Lasano, S.; Narayanan, B. Modulation of PGE2-induced EP4 expression on snail signaling and the impact on epithelial-mesenchymal transition: Significance of EP4 antagonism. Anticancer Res. 2011, 31, 4347-4357. [PubMed]

62. Park, J.Y.; Pillinger, M.H.; Abramson, S.B. Prostaglandin E2 synthesis and secretion: The role of PGE2 synthases. Clin. Immunol. 2006, 119, 229-240. [CrossRef] [PubMed]

63. Caughey, G.E.; Cleland, L.G.; Penglis, P.S.; Gamble, J.R.; James, M.J. Roles of cyclooxygenase (COX)-1 and COX-2 in prostanoid production by human endothelial cells: Selective up-regulation of prostacyclin synthesis by COX-2. J. Immunol. 2001, 167, 2831-2838. [CrossRef] [PubMed]

64. Dinchuk, J.E.; Car, B.D.; Focht, R.J.; Johnston, J.J.; Jaffee, B.D.; Covington, M.B.; Contel, N.R.; Eng, V.M.; Collins, R.J.; Czerniak, P.M. Renal abnormalities and an altered inflammatory response in mice lacking cyclooxygenase II. Nature 1995, 378, 406-409. [CrossRef] [PubMed]

65. Kömhoff, M.; Wang, J.L.; Cheng, H.F.; Langenbach, R.; McKanna, J.A.; Harris, R.C.; Breyer, M.D. Cyclooxygenase-2-selective inhibitors impair glomerulogenesis and renal cortical development. Kidney Int. 2000, 57, 414-422. [CrossRef]

66. Stacey, D.W. Cyclin D1 serves as a cell cycle regulatory switch in actively proliferating cells. Curr. Opin. Cell Biol. 2003, 15, 158-163. [CrossRef]

67. Diehl, J.A.; Cheng, M.; Roussel, M.F.; Sherr, C.J. Glycogen synthase kinase- $3 \beta$ regulates cyclin D1 proteolysis and subcellular localization. Genes Dev. 1998, 12, 3499-3511. [CrossRef] [PubMed]

68. Baldin, V.; Lukas, J.; Marcote, M.J.; Pagano, M.; Draetta, G. Cyclin D1 is a nuclear protein required for cell cycle progression in G1. Genes Dev. 1993, 7, 812-821. [CrossRef] [PubMed]

69. Yamamoto, E.; Izawa, T.; Juniantito, V.; Kuwamura, M.; Sugiura, K.; Takeuchi, T.; Yamate, J. Involvement of endogenous prostaglandin E2 in tubular epithelial regeneration through inhibition of apoptosis and epithelial-mesenchymal transition in cisplatin-induced rat renal lesions. Histol. Histopathol. 2010, 25, 995-1007. [PubMed]

70. Yamamoto, E.; Izawa, T.; Kuwamura, M.; Yamate, J. Immunohistochemical expressions of main PGE 2 biosynthesis-related enzymes and $\mathrm{PGE}_{2}$ receptor in rat nephrogenesis. J. Toxicol. Pathol. 2011, 24, 257-261. [CrossRef] [PubMed]

71. Bolignano, D.; Donato, V.; Coppolino, G.; Campo, S.; Buemi, A.; Lacquaniti, A.; Buemi, M. Neutrophil gelatinase-associated lipocalin (NGAL) as a marker of kidney damage. Am. J. Kidney Dis. 2008, 52, 595-605. [CrossRef] [PubMed]

72. Vaidya, V.S.; Ferguson, M.A.; Bonventre, J.V. Biomarkers of acute kidney injury. Annu. Rev. Pharmacol. Toxicol. 2008, 48, 463-493. [CrossRef] [PubMed]

73. Cernaro, V.; Lacquaniti, A.; Donato, V.; Fazio, M.R.; Buemi, A.; Buemi, M. Fibrosis, regeneration and cancer: What is the link? Nephrol. Dial. Transpl. 2012, 27, 21-27. [CrossRef] [PubMed]

74. Nickolas, T.L. Sensitivity and specificity of a single emergency department measurement of urinary neutrophil gelatinase-associated lipocalin for diagnosing acute kidney injury. Ann. Intern. Med. 2008, 148, 810-819. [CrossRef] [PubMed]

75. Mishra, J.; Mori, K.; Ma, Q.; Kelly, C.; Barasch, J.; Devarajan, P. Neutrophil gelatinase-associated lipocalin: A novel early urinary biomarker for cisplatin nephrotoxicity. Am. J. Nephrol. 2004, 24, 307-315. [CrossRef] [PubMed] 
76. Yu, X.Q.; Wu, L.L.; Huang, X.R.; Yang, N.; Gilbert, R.E.; Cooper, M.E.; Johnson, R.J.; Lai, K.N.; Lan, H.Y. Osteopontin expression in progressive renal injury in remnant kidney: Role of angiotensin II. Kidney Int. 2000, 58, 1469-1480. [CrossRef] [PubMed]

77. Xie, Y.; Sakatsume, M.; Nishi, S.; Narita, I.; Arakawa, M.; Gejyo, F. Expression, roles, receptors, and regulation of osteopontin in the kidney. Kidney Int. 2001, 60, 1645-1657. [CrossRef] [PubMed]

78. Shevde, L.A.; Samant, R.S. Role of osteopontin in the pathophysiology of cancer. Matrix Biol. 2014, 37, 131-141. [CrossRef] [PubMed]

79. Kashiwagi, E.; Tonomura, Y.; Kondo, C.; Masuno, K.; Fujisawa, K.; Tsuchiya, N.; Matsushima, S.; Torii, M.; Takasu, N.; Izawa, T.; et al. Involvement of neutrophil gelatinase-associated lipocalin and osteopontin in renal tubular regeneration and interstitial fibrosis after cisplatin-induced renal failure. Exp. Toxicol. Pathol. 2014, 66, 301-311. [CrossRef] [PubMed]

80. Yano, R.; Golbar, H.M.; Izawa, T.; Sawamoto, O.; Kuwamura, M.; Yamate, J. Participation of bone morphogenetic protein (BMP)-6 and osteopontin in cisplatin (CDDP)-induced rat renal fibrosis. Exp. Toxicol. Pathol. 2015, 67, 99-107. [CrossRef] [PubMed]

81. Xu, D.; Chen, X.; Deng, Z.; Tan, R.; Liu, C.; Lu, P.; Zhang, W.; Gu, M. Osteopontin mediating cyclosporine A induced epithelial-to-mesenchymal transition on rat renal tubular epithelial cells. Cell Biol. Int. 2014, 38, 8-15. [CrossRef] [PubMed]

82. Yang, J.; Yan, L.; Moses, M.A. Overexpression of neutrophil gelatinase-associated lipocalin (NGAL) induces epithelial-mesenchymal transition in MCF-7 breast cancer cells. Cancer Res. 2005, 65, 1328.

83. Gheorgheosu, D.; Jung, M.; Ören, B.; Schmid, T.; Dehelean, C.; Muntean, D.; Brüne, B. Betulinic acid suppresses NGAL-induced epithelial-to-mesenchymal transition in melanoma. Biol. Chem. 2013, 394, 773-781. [CrossRef] [PubMed]

84. Nakashima, M.; Toyono, T.; Murakami, T.; Akamine, A. Transforming growth factor- $\beta$ superfamily members expressed in rat incisor pulp. Arch. Oral Biol. 1998, 43, 745-751. [CrossRef]

85. Long, J.; Badal, S.S.; Wang, Y.; Chang, B.H.J.; Rodriguez, A.; Danesh, F.R. MicroRNA-22 is a master regulator of bone morphogenetic protein-7/6 homeostasis in the kidney. J. Biol. Chem. 2013, 288, 36202-36214. [CrossRef] [PubMed]

86. Wang, W.; Koka, V.; Lan, H.Y. Transforming growth factor- $\beta$ and Smad signalling in kidney diseases. Nephrology 2005, 10, 48-56. [CrossRef] [PubMed]

87. Lee, S.-Y.; Kim, S.I.; Choi, M.E. Therapeutic targets for treating fibrotic kidney diseases. Transl. Res. 2015, 165, 512-530. [CrossRef] [PubMed]

88. Meng, X.-M.; Chung, A.C.K.; Lan, H.Y. Role of the TGF- $\beta$ /BMP-7/Smad pathways in renal diseases. Clin. Sci. 2013, 124, 243-254. [CrossRef] [PubMed]

89. Manson, S.R.; Niederhoff, R.A.; Hruska, K.A.; Austin, P.F. The BMP-7-Smad1/5/8 pathway promotes kidney repair after obstruction induced renal injury. J. Urol. 2011, 185, 2523-2530. [CrossRef] [PubMed]

90. Luo, D.D.; Phillips, A.; Fraser, D. Bone morphogenetic protein-7 inhibits proximal tubular epithelial cell Smad3 signaling via increased SnoN expression. Am. J. Pathol. 2010, 176, 1139-11347. [CrossRef] [PubMed]

91. Li, R.X.; Yiu, W.H.; Tang, S.C.W. Role of bone morphogenetic protein-7 in renal fibrosis. Front. Physiol. 2015, 6, 114. [CrossRef] [PubMed]

92. Dendooven, A.; van Oostrom, O.; van der Giezen, D.M.; Leeuwis, J.W.; Snijckers, C.; Joles, J.A.; Robertson, E.J.; Verhaar, M.C.; Nguyen, T.Q.; Goldschmeding, R. Loss of endogenous bone morphogenetic protein-6 aggravates renal fibrosis. Am. J. Pathol. 2011, 178, 1069-1079. [CrossRef] [PubMed]

93. Yan, J.-D.; Yang, S.; Zhang, J.; Zhu, T.-H. BMP6 reverses TGF- $\beta 1$-induced changes in HK-2 cells: Implications for the treatment of renal fibrosis. Acta Pharmacol. Sin. 2009, 30, 994-1000. [CrossRef] [PubMed]

94. Zeisberg, M.; Hanai, J.; Sugimoto, H.; Mammoto, T.; Charytan, D.; Strutz, F.; Kalluri, R. BMP-7 counteracts TGF- $\beta 1$-induced epithelial-to-mesenchymal transition and reverses chronic renal injury. Nat. Med. 2003, 9, 964-968. [CrossRef] [PubMed]

95. Uehara, T.; Ainslie, G.R.; Kutanzi, K.; Pogribny, I.P.; Muskhelishvili, L.; Izawa, T.; Yamate, J.; Kosyk, O.; Shymonyak, S.; Bradford, B.U.; et al. Molecular mechanisms of fibrosis-associated promotion of liver carcinogenesis. Toxicol. Sci. 2013, 132, 53-63. [CrossRef] [PubMed] 
96. Wijesundera, K.K.; Izawa, T.; Tennakoon, A.H.; Murakami, H.; Golbar, H.M.; Katou-Ichikawa, C.; Tanaka, M.; Kuwamura, M.; Yamate, J. M1- and M2-macrophage polarization in rat liver cirrhosis induced by thioacetamide (TAA), focusing on Iba1 and galectin-3. Exp. Mol. Pathol. 2014, 96, 382-392. [CrossRef] [PubMed]

97. Goodman, Z.D.; Ishak, K.G. Histopathology of hepatitis C virus infection. Semin. Liver Dis. 1995, 15, 70-81. [CrossRef] [PubMed]

98. Michalopoulos, G.K. Liver regeneration: Alternative epithelial pathways. Int. J. Biochem. Cell Biol. 2011, 43, 173-179. [CrossRef] [PubMed]

99. Brenner, D.A. Reversibility of liver fibrosis. Gastroenterol. Hepatol. 2013, 9, 737-739.

100. Stickel, F. Alcoholic cirrhosis and hepatocellular carcinoma. Adv. Exp. Med. Biol. 2015, 815, 113-130. [PubMed]

101. Iwaisako, K.; Taura, K.; Koyama, Y.; Takemoto, K.; Asagiri, M. Strategies to detect hepatic myofibroblasts in liver cirrhosis of different etiologies. Curr. Pathobiol. Rep. 2014, 2, 209-215. [CrossRef] [PubMed]

102. Liedtke, C.; Luedde, T.; Sauerbruch, T.; Scholten, D.; Streetz, K.; Tacke, F.; Tolba, R.; Trautwein, C.; Trebicka, J.; Weiskirchen, R. Experimental liver fibrosis research: Update on animal models, legal issues and translational aspects. Fibrogenesis Tissue Repair 2013, 6, 19. [CrossRef] [PubMed]

103. Tennakoon, A.H.; Izawa, T.; Wijesundera, K.K.; Katou-Ichikawa, C.; Tanaka, M.; Golbar, H.M.; Kuwamura, M.; Yamate, J. Analysis of glial fibrillary acidic protein (GFAP)-expressing ductular cells in a rat liver cirrhosis model induced by repeated injections of thioacetamide (TAA). Exp. Mol. Pathol. 2015, 98, 476-485. [CrossRef] [PubMed]

104. Golbar, H.M.; Izawa, T.; Wijesundera, K.K.; Tennakoon, A.H.; Katou-Ichikawa, C.; Tanaka, M.; Kuwamura, M.; Yamate, J. Expression of nestin in remodelling of $\alpha$-naphthylisothiocyanate-induced acute bile duct injury in rats. J. Comp. Pathol. 2014, 151, 255-263. [CrossRef] [PubMed]

105. Noda, S.; Masumi, S.; Moriyama, M.; Kannan, Y.; Ohta, M.; Sugano, T.; Yamate, J. Population of hepatic macrophages and response of perfused liver to platelet-activating factor during production of thioacetamide-induced cirrhosis in rats. Hepatology 1996, 24, 412-418. [CrossRef] [PubMed]

106. Yovchev, M.I.; Xue, Y.; Shafritz, D.A.; Locker, J.; Oertel, M. Repopulation of the fibrotic/cirrhotic rat liver by transplanted hepatic stem/progenitor cells and mature hepatocytes. Hepatology 2014, 59, 284-295. [CrossRef] [PubMed]

107. Desmet, V.J.; Krstulović, B.; van Damme, B. Histochemical study of rat liver in $\alpha$-naphthyl isothiocyanate (ANIT) induced cholestasis. Am. J. Pathol. 1968, 52, 401-421. [PubMed]

108. Lesage, G.; Glaser, S.; Ueno, Y.; Alvaro, D.; Baiocchi, L.; Kanno, N.; Phinizy, J.L.; Francis, H.; Alpini, G. Regression of cholangiocyte proliferation after cessation of ANIT feeding is coupled with increased apoptosis. Am. J. Physiol. Gastrointest. Liver Physiol. 2001, 281, G182-G190. [PubMed]

109. Tjandra, K.; Sharkey, K.A.; Swain, M.G. Progressive development of a Th1-type hepatic cytokine profile in rats with experimental cholangitis. Hepatology 2000, 31, 280-290. [CrossRef] [PubMed]

110. Iwaisako, K.; Jiang, C.; Zhang, M.; Cong, M.; Moore-Morris, T.J.; Park, T.J.; Liu, X.; Xu, J.; Wang, P.; Paik, Y.-H.; et al. Origin of myofibroblasts in the fibrotic liver in mice. Proc. Natl. Acad. Sci. 2014, 111, E3297-E3305. [CrossRef] [PubMed]

111. Xu, J.; Liu, X.; Brenner, D.; Kisseleva, T. Novel perspectives on the origins of the hepatic myofibroblasts. Cell Health Cytoskelet. 2015, 7, 111-119. [CrossRef]

112. Brenner, D.A.; Kisseleva, T.; Scholten, D.; Paik, Y.H.; Iwaisako, K.; Inokuchi, S.; Schnabl, B.; Seki, E.; de Minicis, S.; Oesterreicher, C.; et al. Origin of myofibroblasts in liver fibrosis. Fibrogenesis Tissue Repair 2012, 5, S17. [CrossRef] [PubMed]

113. Kalluri, R.; Neilson, E.G. Epithelial-mesenchymal transition and its implications for fibrosis. J. Clin. Investig. 2003, 112, 1776-1784. [CrossRef] [PubMed]

114. Bataller, R.; Brenner, D.A. Liver fibrosis. J. Clin. Investig. 2005, 115, 209-218. [CrossRef] [PubMed]

115. Kaimori, A.; Potter, J.; Kaimori, J.-Y.; Wang, C.; Mezey, E.; Koteish, A. Transforming growth factor- $\beta 1$ induces an epithelial-to-mesenchymal transition state in mouse hepatocytes in vitro. J. Biol. Chem. 2007, 282, 22089-22101. [CrossRef] [PubMed]

116. Zeisberg, M.; Yang, C.; Martino, M.; Duncan, M.B.; Rieder, F.; Tanjore, H.; Kalluri, R. Fibroblasts derive from hepatocytes in liver fibrosis via epithelial to mesenchymal transition. J. Biol. Chem. 2007, 282, 23337-23347. [CrossRef] [PubMed] 
117. Xia, J.-L.; Dai, C.; Michalopoulos, G.K.; Liu, Y. Hepatocyte growth factor attenuates liver fibrosis induced by bile duct ligation. Am. J. Pathol. 2006, 168, 1500-1512. [CrossRef] [PubMed]

118. Omenetti, A.; Porrello, A.; Jung, Y.; Yang, L.; Popov, Y.; Choi, S.S.; Witek, R.P.; Alpini, G.; Venter, J.; Vandongen, H.M.; et al. Hedgehog signaling regulates epithelial-mesenchymal transition during biliary fibrosis in rodents and humans. J. Clin. Investig. 2008, 118, 3331-3342. [CrossRef] [PubMed]

119. Yovchev, M.I.; Grozdanov, P.N.; Zhou, H.; Racherla, H.; Guha, C.; Dabeva, M.D. Identification of adult hepatic progenitor cells capable of repopulating injured rat liver. Hepatology 2008, 47, 636-647. [CrossRef] [PubMed]

120. Díaz, R.; Kim, J.W.; Hui, J.-J.; Li, Z.; Swain, G.P.; Fong, K.S.K.; Csiszar, K.; Russo, P.A.; Rand, E.B.; Furth, E.E.; et al. Evidence for the epithelial to mesenchymal transition in biliary atresia fibrosis. Hum. Pathol. 2008, 39, 102-115. [CrossRef] [PubMed]

121. Desmet, V.; Roskams, T.; van Eyken, P. Ductular reaction in the livers. Pathol. Res. Pract. 1995, 191, 513-524. [CrossRef]

122. Zhou, H.; Rogler, L.E.; Teperman, L.; Morgan, G.; Rogler, C.E. Identification of hepatocytic and bile ductular cell lineages and candidate stem cells in bipolar ductular reactions in cirrhotic human liver. Hepatology 2007, 45, 716-724. [CrossRef] [PubMed]

123. Clouston, A.D.; Powell, E.E.; Walsh, M.J.; Richardson, M.M.; Demetris, A.J.; Jonsson, J.R. Fibrosis correlates with a ductular reaction in hepatitis C: Roles of impaired replication, progenitor cells and steatosis. Hepatology 2005, 41, 809-818. [CrossRef] [PubMed]

124. Tremblay, K.D.; Zaret, K.S. Distinct populations of endoderm cells converge to generate the embryonic liver bud and ventral foregut tissues. Dev. Biol. 2005, 280, 87-99. [CrossRef] [PubMed]

125. Strazzabosco, M.; Fabris, L. Development of the bile ducts: Essentials for the clinical hepatologist. J. Hepatol. 2012, 56, 1159-1170. [CrossRef] [PubMed]

126. Carpentier, R.; Suñer, R.E.; van Hul, N.; Kopp, J.L.; Beaudry, J.-B.; Cordi, S.; Antoniou, A.; Raynaud, P.; Lepreux, S.; Jacquemin, P.; et al. Embryonic ductal plate cells give rise to cholangiocytes, periportal hepatocytes, and adult liver progenitor cells. Gastroenterology 2011, 141, 1432-1438. [CrossRef] [PubMed]

127. Gaudio, E.; Carpino, G.; Cardinale, V.; Franchitto, A.; Onori, P.; Alvaro, D. New insights into liver stem cells. Dig. Liver Dis. 2009, 41, 455-462. [CrossRef] [PubMed]

128. Capurro, M.I.; Xiang, Y.-Y.; Lobe, C.; Filmus, J. Glypican-3 promotes the growth of hepatocellular carcinoma by stimulating canonical Wnt signaling. Cancer Res. 2005, 65, 6245-6254. [CrossRef] [PubMed]

129. Yuzugullu, H.; Benhaj, K.; Ozturk, N.; Senturk, S.; Celik, E.; Toylu, A.; Tasdemir, N.; Yilmaz, M.; Erdal, E.; Akcali, K.C.; et al. Canonical Wnt signaling is antagonized by noncanonical Wnt5a in hepatocellular carcinoma cells. Mol. Cancer 2009, 8, 90. [CrossRef] [PubMed]

130. Yang, W.; Yan, H.-X.; Chen, L.; Liu, Q.; He, Y.-Q.; Yu, L.-X.; Zhang, S.-H.; Huang, D.-D.; Tang, L.; Kong, X.-N.; et al. Wnt/ $\beta$-catenin signaling contributes to activation of normal and tumorigenic liver progenitor cells. Cancer Res. 2008, 68, 4287-4295. [CrossRef] [PubMed]

131. Sell, S.; Leffert, H.L. Liver cancer stem cells. J. Clin. Oncol. 2008, 26, 2800-2805. [CrossRef] [PubMed]

132. Chen, J.; Zhang, X.; Xu, Y.; Li, X.; Ren, S.; Zhou, Y.; Duan, Y.; Zern, M.; Zhang, H.; Chen, G.; et al. Hepatic progenitor cells contribute to the progression of 2-acetylaminofluorene/carbon tetrachloride-induced cirrhosis via the non-canonical Wnt pathway. PLoS ONE 2015, 10, e0130310. [CrossRef] [PubMed]

133. Wang, P.; Liu, T.; Cong, M.; Wu, X.; Bai, Y.; Yin, C.; An, W.; Wang, B.; Jia, J.; You, H. Expression of extracellular matrix genes in cultured hepatic oval cells: An origin of hepatic stellate cells through transforming growth factor $\beta$ ? Liver Int. 2009, 29, 575-584. [CrossRef] [PubMed]

134. Sicklick, J.K.; Choi, S.S.; Bustamante, M.; McCall, S.J.; Pérez, E.H.; Huang, J.; Li, Y.-X.; Rojkind, M.; Diehl, A.M. Evidence for epithelial-mesenchymal transitions in adult liver cells. Am. J. Physiol. Gastrointest. Liver Physiol. 2006, 291, G575-G583. [CrossRef] [PubMed]

135. Teng, Y.; Zeisberg, M.; Kalluri, R. Transcriptional regulation of epithelial-mesenchymal transition. J. Clin. Investig. 2007, 117, 304-306. [CrossRef] [PubMed]

136. Chu, A.S.; Diaz, R.; Hui, J.-J.; Yanger, K.; Zong, Y.; Alpini, G.; Stanger, B.Z.; Wells, R.G. Lineage tracing demonstrates no evidence of cholangiocyte epithelial-to-mesenchymal transition in murine models of hepatic fibrosis. Hepatology 2011, 53, 1685-1695. [CrossRef] [PubMed] 
137. Kordes, C.; Sawitza, I.; Müller-Marbach, A.; Ale-Agha, N.; Keitel, V.; Klonowski-Stumpe, H.; Häussinger, D. $\mathrm{CD}_{133^{+}}$hepatic stellate cells are progenitor cells. Biochem. Biophys. Res. Commun. 2007, 352, 410-417. [CrossRef] [PubMed]

138. Yang, L.; Jung, Y.; Omenetti, A.; Witek, R.P.; Choi, S.; Vandongen, H.M.; Huang, J.; Alpini, G.D.; Diehl, A.M. Fate-mapping evidence that hepatic stellate cells are epithelial progenitors in adult mouse livers. Stem Cells 2008, 26, 2104-2113. [CrossRef] [PubMed] 